\title{
POJĘCIE DOMU ZAKONNEGO I JEGO ZNACZENIE W ŻYCIU ZAKONNYM
}

Treść: Wprowadzenie. - 1. Terminologia dotycząca domu zakonnego. - 2. Istotne elementy domu zakonnego. - 2.1. Wspólnota braterska. - 2.2. Przełożony wspólnoty. - 2.3. Kaplica. - 2.4. Prawne ustanowienie.- 3. Definicja domu zakonnego. 4. Obowiązek przebywania przez zakonnika w domu zakonnym. - 5. Sens zamieszkiwania przez zakonnika w domu prawnie ustanowionym. - 5.1. Oddzielenie od świata. - 5.2. Wspólnota zakonna znakiem Kościoła-komunii. - 5.3. Realizacja ślubów zakonnych. - Zakończenie.

\section{Wprowadzenie}

W definicji życia zakonnego podanej w kanonie 607 Kodeksu Prawa Kanonicznego z 1983 roku podkreśla się, że jest ono życiem braterskim prowadzonym przez zakonników we wspólnocie. Wymóg wspólnoty z kolei pociąga za sobą konieczność zamieszkania jej członków w jednym domu zakonnym. Powstaje pytanie, czy określenie „dom zakonny", stosowane często przez samych zakonników, jest terminem w pełni komunikatywnym w tym środowisku, czy też raczej jego rozumienie bywa bardzo uproszczone i ogranicza się tylko do budynku. Na początku warto przyjrzeć się dokładniej samemu pojęciu domu zakonnego, a następnie właściwemu znaczeniu domu w życiu zakonnika.

\section{Terminologia dotycząca domu zakonnego}

Nazwa „dom zakonny”, stosowana w prawie kanonicznym podlegała historycznej ewolucji, mając wiele określeń bliskoznacznych, które odnosiły się zasadniczo do budynku zamieszkanego przez osoby poświęcone w sposób szczególny Bogu. W przeszłości miejsce ich in- 
dywidualnego lub grupowego przebywania nazywano m.in. terminami: loca pia, casa pia, hospitium, orphanotrophium, institutum ecclesiasticum, nosocomium oraz monasterium.

W IV wieku św. Pachomiusz zapoczątkował nową formę monastycyzmu zwaną cenobityzmem, budując mnichom mieszkającym dotychczas w pojedynkę cele oraz pomieszczenia, w których wspólnie modlili się, spożywali posiłki i wykonywali różne prace. Siedzibę cenobitów nazywano najczęściej cenobium, ale stosowano także inne terminy, takie jak monasterium i asceterium, a w zakonach żebrzących - conventus, u jezuitów natomiast i w nowo powstających instytutach residentia dla odróżnienia od collegium, gdzie zakonnicy odbywali studia. Sobór Trydencki (1545-1563) dążył do ujednolicenia nazewnictwa związanego z miejscem zamieszkania zakonników, zalecając stosowanie określenia monasterium na oznaczenie domu niezależnego (autonomicznego, sui iuris) dawnych mnichów i mniszek. Z tego typu domami zakonnicy związani są na stałe węzłem złożonej profesji lub obietnicy, a przełożony bądź przełożona klasztoru należą do przełożonych wyższych, wybieranych przez zakonników danego klasztoru według norm prawa własnego. Natomiast określenia „dom” i „dom zakonny" nabierały stopniowo znaczenia ogólnego i odnosiły się do każdego domu należącego do instytutu zakonnego ${ }^{1}$. Dlatego też Kodeks Prawa Kanonicznego z 1917 roku podawał, że dom zakonny jest to dom jakiegoś zakonu w ogólności (,domus alicuius religionis in genere”)2. Jednocześnie wyjaśniał termin „domu regularnego” tj. domu zakonu ścisłego, a więc takiego, w którym składano śluby uroczyste, a także „domu uformowanego”, czyli takiego, w którym przebywało przynajmniej sześciu zakonników po profesji, a w zakonach kleryckich przynajmniej czterech z nich było kapłanami. Domy nie spełniające wymienionych wymogów nazywano „domami nieuformowanymi”.

${ }^{1}$ M. DANILUK, Encyklopedia instytutów życia konsekrowanego i stowarzyszeń życia apostolskiego, Lublin 2000, s. 98; G.J. VAN DEN BRoECK, Casa religiosa, w: Dizionario degli Istituti di Perfezione (odtąd: DIP), t. II, Roma 1975, kol. 625-628.

2-KPK/1917, kan. 488, $5^{\circ}$.

${ }^{3}$ KPK/1917, kan. 488, 5 ; F. BĄCZKowicz, Prawo kanoniczne. Podręcznik dla duchowieństwa, t. I, Opole $1957^{3}$, s. 627. 
Kodeks Prawa Kanonicznego z 1983 r. stosuje terminy: dom nowicjatu $^{4}$, dom instytutu, dom zakonny ${ }^{5}$, dom lub klasztor niezależny (sui iuris) na oznaczenie domu zakonnego kanoników regularnych i mnichów oraz mniszek ${ }^{6}$.

W zależności od przeznaczenia domów zakonnych można wśród nich wyróżnić dom macierzysty, czyli najczęściej pierwszy dom, z którego instytut się wywodzi; dom filialny, który nie posiada osobowości prawnej i jest zależny od innego domu zakonnego; dom nowicjatu, przeznaczony na kształcenie nowicjuszy; dom formacyjny, w którym odbywają się postulat i juniorat oraz dom główny (generalny), stanowiący miejsce rezydencji zarządu generalnego instytutu.

\section{Istotne elementy domu zakonnego}

Prawodawca w kanonie 608 KPK/1983 r., który rozpoczyna obowiązującą regulację prawną dotyczącą domu zakonnego, nie podaje jego precyzyjnej definicji, lecz koncentruje się na zasadniczych elementach domu. $\mathrm{Z}$ kanonu wynika, że z domem zakonnym nierozerwalnie związana jest zamieszkująca go wspólnota zakonników, osoba przełożonego oraz kaplica jako miejsce sprawowania i przechowywania Eucharystii będącej centrum wspólnoty zakonnej, a także prawne ustanowienie domu.

\subsection{Wspólnota braterska}

Życie wspólne zakonników, określane dziś mianem życia braterskiego we wspólnocie ${ }^{8}$ lub braterskiej wspólnoty w Chrystusie ${ }^{9}$, stanowi pryncypialny element instytutów zakonnych i jest tak ściśle związane z pojęciem domu zakonnego, że terminy dom zakonny i wspól-

4 KPK/1983, kan. 647.

5 KPK/1983, kan. 608-616, 647.

${ }^{6} \mathrm{KPK} / 1983$, kan. 613-615.

7 B. Zubert, Dom zakonny, w: Encyklopedia katolicka, t. IV, Lublin 1983, kol. 50; M. DANILUK, Encyklopedia instytutów życia konsekrowanego..., s. 98; M. SAJ, Konstytutywne elementy domu zakonnego, Prawo Kanoniczne 51 (2008) nr 3-4, s. 148-152.

${ }^{8} \mathrm{KPK} / 1983$, kan. 607 \$2.

9 KPK/1983, kan. 619. 
nota zakonna stosuje się często zamiennie ${ }^{10}$. Stąd do zaistnienia domu zakonnego konieczne jest, aby kilku członków tego samego instytutu przebywało na stałe w jednym budynku, zachowując wspólnotę stołu, używając tych samych sprzętów zgodnie z ubóstwem przepisanym prawem własnym, uczestniczyło we wspólnych modlitwach, zachowywało te same konstytucje, dyrektorium i regułę oraz nosiło jednakowy strój przyjęty w instytucie ${ }^{11}$. Trzeba w tym miejscu zauważyć, że według św. Pachomiusza i innych wielkich zakonodawców, jak św. Bazyli, św. Augustyn i św. Benedykt, zamieszkanie razem i prowadzenie życia wspólnego w wymiarze zewnętrznym, materialnym nie wyczerpuje jeszcze istoty życia braterskiego we wspólnocie. Wszyscy oni, gromadząc razem współbraci, nawiązywali do obrazu pierwszej wspólnoty jerozolimskiej chrześcijan, których do wspólnego przebywania motywowała w głównej mierze wiara i miłość do Chrystusa. Wszystkich ożywiał jeden duch i jedno serce, łamali chleb i przyjmowali posiłek z radością i prostotą, trwali w nauce Apostołów, w nieustannej modlitwie, uwielbianiu Boga, a nikt nie nazywał swoim tego, co posiadał, nikt nie cierpiał niedostatku, gdyż niektórzy sprzedawali swe majątki i dobra rozdzielano wszystkim według ich potrzeby ${ }^{12}$. To właśnie radość braterstwa w Chrystusie, pragnienie wspólnego oddawania chwały Bogu, dzielenie dóbr i wspólnie spożywane posiłki skłaniały pierwszych chrześcijan do wspólnego zamieszkania i przebywania ze sobą na stałe. Tak więc bez ducha braterstwa właściwego pierwszym chrześcijanom także obecnie wspólne zamieszkiwanie zakonników w jednym domu nie ma charakteru nadprzyrodzonego i przypomina raczej pobyt żołnierzy w koszarach lub więźniów w zakładzie karnym i nie jest życiem braterskim we wspólnocie.

${ }^{10} \mathrm{D}$. AndrÉs, Le forme di vita consacrata. Commentario teologico-giuridico al Codice di diritto canonico, Roma 20055, 114-115; M. STokŁosA, La figura del superiore provinciale nel nuovo Codice di Diritto Canonico e nel diritto proprio della Congregazione dei Sacerdoti del Sacro Cuore di Gesù, Roma 2007, s. 235; L. ChIAPETtA, Il codice di diritto canonico. Commento giuridico-pastorale, Roma 1996, t. I, s. 749.

${ }^{11}$ G.J. Van den Broeck, Casa religiosa..., kol. 626.

${ }^{12}$ Dz 2, 42-47; Dz 4, 32-37. 
Zamysł wielkich zakonodawców dotyczący istoty życia wspólnego w wymiarze duchowym zagubił się jednak z upływem wieków i życie wspólne zaczęto utożsamiać z jego wymiarem zewnętrznym. Sobór Trydencki sprowadził je do obowiązku przebywania w klasztorze, tj. zachowania ścisłej klauzury, przestrzegania jednakowego porządku dnia (tj. obserwancji), korzystania przez wszystkich członków wspólnoty z tego samego pożywienia, odzieży i takich samych sprzętów, unikania wszystkiego, co może stać w sprzeczności ze ślubem ubóstwa, ale jednocześnie zapewnienie zakonnikom tego, co jest im niezbędne do życia i rozwoju powołania ${ }^{13}$.

Kodeks z 1917 r. przejął myśl wcześniejszego ustawodawstwa kościelnego i ujmował życie wspólne podobnie tj. jako zachowanie przez wszystkich zakonników tego, co dotyczy wyżywienia, ubioru i używania sprzętów ${ }^{14}$.

Sobór Watykański II, a za nim KPK/1983 przypominają, że życie wspólne zakonników ma swój wzór w Kościele pierwotnym. W dekrecie soborowym Perfectae caritatis oraz w KPK/1983 na pierwszym miejscu wymienia się elementy duchowe, wewnętrzne wspólnoty zakonnej, tj. jej oparcie się na modlitwie i wspólnocie tego samego Ducha oraz podtrzymywanie nauką ewangeliczną, świętą liturgią, a zwłaszcza Eucharystią. Wspólnota zakonna powinna stanowić prawdziwą rodzinę zgromadzoną w imię Chrystusa i radować się Jego obecnością ${ }^{15}$. Dopiero w przypadku takiego węzła braterstwa między członkami wspólnoty jej elementy zewnętrze wynikające ze wspólnego zamieszkania nabierają sensu i sprzyjają pogłębieniu relacji pomiędzy zakonnikami oraz między nimi a Bogiem.

\subsection{Przełożony wspólnoty}

Już św. Pachomiusz ustanowił w swych wspólnotach przełożonych będących dla pozostałych cenobitów przedstawicielami Boga oraz

${ }^{13}$ Sobór Trydencki (1545-1563), Sesja XXV, Dekret $w$ sprawie zakonników i zakonnic, w: Dokumenty soborów powszechnych. Tekst grecki, łaciński, polski, t. IV (1511-1870) Kraków 2005, s. 785-809.

14 KPK/1983, kan. 594, §1.

${ }^{15}$ PC, nr 15; KPK/1983, kan. 602, 619. 
wyrazicielami Jego woli. Taką właśnie organizację zaczerpnął on ze struktury Kościoła pierwotnego, który również miał pasterzy powołanych przez Boga ${ }^{16}$. Św. Benedykt z Nursji z kolei wyjaśnił w swojej Regule, że podwładni w klasztorze powinni widzieć w przełożonym zastępcę Chrystusa ${ }^{17}$. Przełożony zaś, nazywany często $A b b a$, zdając sobie sprawę z tego, jak go podwładni nazywają i kim jest, powinien wciąż pamiętać, że podjął się trudnego zadania „rządzenia duszami”. Stąd jego pierwszym zadaniem miała być troska o zbawienie dusz podwładnych, nie zaś zabieganie o rzeczy materialne i przemijające, związane z życiem klasztornym. Powinien zajmować się podwładnymi i gorliwie usuwać nieprawidłowości w życiu wspólnoty, czyli „leczyć choroby jej postępowania”, gdyż z tej właśnie funkcji będzie musiał zdać kiedyś sprawę przed Bogiem ${ }^{18}$.

KPK/1983 w kan. 608, nawiązując do zamysłu pierwszych zakonodawców, potwierdził konieczność wyznaczenia zgodnie z prawem dla każdego domu zakonnego przełożonego będącego członkiem wspólnoty. Warto zauważyć, że komentatorzy tego kanonu zgodnie podkreślają, iż dom bez przełożonego nie może nazywać się domem zakonnym $^{19}$. I tak jak dom zakonny (klasztor) stanowił pierwszą rzeczywistość społeczno-prawną, w której życie zakonne znalazło swój wyraz, tak też przełożony klasztoru był pierwszym przełożonym zakonnym, zanim wraz $\mathrm{z}$ wprowadzeniem hierarchicznej struktury władzy w zakonach pojawili się przełożeni prowincjalni i generalni ${ }^{20}$. Trzeba w tym miejscu nadmienić, że w ramach posoborowej odnowy życia zakonnego miały miejsce próby likwidacji urzędu przełożonego w niektórych wspólnotach zakonnych lub ograniczenia jego władzy tylko do roli koordynatora inicjatyw podejmowanych kolegialnie przez członków

${ }^{16}$ A. DE VogüÉ, Il monachesimo antico, DIP, t. X, Roma 2003, kol. 287.

${ }^{17}$ Benedykt z Nursj, Reguła, (przekład A. ŚwiderkównA), Tyniec 1997², nr 2.

${ }^{18}$ Tamże.

${ }^{19}$ D. Andrés, Le forme di vita consacrata. Commentario teologico-giuridico..., s. 116: „Senza la sua [del superiore - B. Sz.] presenza, non puo esistere vera casa religiosa canonica”; J. Torres, Le case religiose, Roma 1994-1995, s. 9: „ma senza superiore della casa, questa non puo considerarsi religiosa".

${ }^{20}$ J. TORRES, Le case religiose, Roma 1994-1995, s. 8. 
wspólnoty. Praktyki te jednak jeszcze bardziej potwierdziły potrzebę istnienia przełożonego i jego znaczenie w życiu zakonnym, a poza tym nie spotkały się z aprobatą Stolicy Apostolskiej ${ }^{21}$.

KPK/1983 przypomina, że przełożeni otrzymują swą władzę od Boga przez posługę Kościoła i powinni wykonywać ją w duchu służby. Ich zadaniem jest szukanie przede wszystkim woli Bożej zarówno w stosunku do poszczególnych podwładnych, jak i całych wspólnot. W wykonywaniu swej posługi powinni kierować podwładnymi jako synami Bożymi, odnosząc się z szacunkiem do ich ludzkiej godności ${ }^{22}$. Zaś liczne obowiązki ascetyczno-duszpasterskie przełożonych wymienione w kan. 619 rozwijają myśl św. Benedykta dotyczącą ważności przede wszystkim duchowej funkcji przełożonego we wspólno$\mathrm{cie}^{23}$. W dalszej kolejności prawodawca reguluje sprawę wyboru lub mianowania przełożonych na określony i odpowiedni przeciąg czasu zgodnie z prawem własnym instytutów, ustala obowiązek korzystania przez nich w wykonywaniu swego urzędu z pomocy rady zalecając

21 Sacra Congregatio pro Religiosis et Institutis Secularibus, Decretum circa regiminis ordinarii rationem et religiosi saecularizati accessum ad officia et beneficia ecclesiastica «Experimenta circa regiminis rationem» 02.02.1972, AAS 64(1972)393394, tekst polski: Kongregacja ZaKonów I InSTYtutów ŚwIECKICH, Dekret «Experimenta circa regimins rationem», w: Paweł VI, Charyzmat życia zakonnego. Przemówienia i dokumenty, (opr. A. Żuchowski, T. Sułowska), Poznań-Warszawa 1974, s. 324-325; Congregavit nos, 48; D. Andrés, Le forme di vita consacrata. Commentario teologico-giuridico..., s. 116.

${ }^{22}$ KPK/1983, kan. 618; Kongregacja Instytutów Życia Konsekrowanego i StoWARZYsZeń Życia Apostolskiego, Instrukcja Posługa władzy i postuszeństwo «Faciem tuam, Domine, requiram», Libreria Editrice Vaticana 2008, nr 4-18 (odtąd: Postuga władzy i postuszeństwo).

${ }^{23}$ KPK/1983, kan. 619: „Przełożeni powinni gorliwie wypełniać swój urząd i wraz z powierzonymi sobie członkami starać się budować braterską w Chrystusie wspólnotę, w której szuka się i miłuje przede wszystkim Boga. Powinni więc karmić często swoich podwładnych słowem Bożym i doprowadzać do sprawowania świętej liturgii. Mają być dla nich przykładem w pielęgnowaniu cnót oraz w zachowywaniu przepisów i tradycji własnego instytutu. Niech starają się zaradzić odpowiednio ich potrzebom, niech troszczą się o chorych i odwiedzają ich, niech poskramiają niespokojnych, pocieszają małodusznych i będą dla wszystkich cierpliwi"; B.W. ZuBERT, Instytuty życia konsekrowanego i stowarzyszenia życia apostolskiego, Komentarz do Kodeksu Prawa Kanonicznego, Księga II. Lud Boży. Czesść III, Lublin 1990, s. 65-69. 
określenie w prawie własnym sytuacji, w których potrzebuje on jej zgody, a w których głosu doradczego. Podstawowymi obowiązkami prawnymi przełożonego są przeprowadzanie wizytacji, troska o odpowiednich spowiedników dla wspólnoty oraz obowiązek rezydencji, czyli przebywania w swoim domu zakonnym i nie opuszczania go poza wypadkami przewidzianymi w prawie własnym dotyczącymi wypełniania powierzonych mu obowiązków ${ }^{24}$.

\subsection{Kaplica}

Drugą część kan. 608, mówiącego o obowiązku zamieszkania przez zakonników w domu zakonnym, prawodawca poświęca konieczności utworzenia w nim kaplicy. Jest to tak ważny wymóg, że żaden dom zakonny nie może być erygowany, jeżeli nie przewiduje się w nim miejsca na kaplicę ${ }^{25}$. Na obowiązek ustanowienia kaplicy wskazuje użycie słowa habeant odnoszącego się konkretnie do każdego pojedynczego domu zakonnego. I nawet gdyby w pobliżu domu zakonnego znajdował się kościół parafialny, mimo wszystko w domu zakonnym prawnie ustanowionym powinna być kaplica ${ }^{26}$. Kaplica, za pozwoleniem ordynariusza, jest miejscem przeznaczonym do sprawowania kultu Bożego dla dobra wspólnoty wiernych, którzy gromadzą się w niej za zgodą kompetentnego przełożonego. Powinno się w niej odprawiać i przechowywać Eucharystię tak, aby stanowiła ona centrum wspólnoty, znak jej jedności i węzeł miłości. Mogą do niej uczęszczać także inni wierni ${ }^{27}$.

${ }^{24} \mathrm{KPK} / 1983$, kan. 624, 627-630.

${ }^{25}$ J. BeYer, Il c. 608 dispone. Il nuovo Codice e il futuro della vita consacrata. Risposte a quesiti e dubbi sul nuovo diritto degli Istituti di Vita Consacrata, Vita Consacrata 21(1985)588.

${ }^{26}$ G. SARZI SARTORI, Commento a un canone. L'Eucaristia al centro della comunità religiosa (c. 608), Quaderni di Diritto Ecclesiale 5(1992), s. 336; K. KAŁowski, Życie braterskie we wspólnocie, Warszawa 1999, s. 188; D. ANDRÉs, Le forme di vita consacrata. Commentario teologico-giuridico..., s. 116.

${ }^{27}$ KPK/1983, kan. 1223; J. KAŁOWSKI, Życie braterskie..., s. 188-189. 
Kaplica jest więc miejscem wokół którego także zewnętrznie skupiają się członkowie wspólnoty ${ }^{28}$. Zresztą jeden z ich podstawowych obowiązków wiąże się siłą rzeczy z koniecznością przebywania w kaplicy lub kościele - jest nim codzienne uczestniczenie we Mszy św., przyjmowanie Komunii św. i adoracja Chrystusa obecnego w Najświętszym Sakramencie ${ }^{29}$.

\subsection{Prawne ustanowienie domu zakonnego}

Wzmiankowany kanon 608 KPK/1983 przewiduje konieczność prawnego ustanowienia domu zakonnego. Ponieważ prawodawca nie stosuje w tym miejscu terminu erekcja, lecz mówi o ustanawianiu domów zakonnych, istnieją odmienne opinie kanonistów co do znaczenia pojęcia domu prawnie ustanowionego. Niektórzy z nich, tacy jak V. de Paolis, F.X. Egaña, i J. Beyer wyróżniają domy ustanowione, o których mowa w kan. 608 i erygowane (kan. 609), stwierdzając wyraźnie, że ustanowienie domu zakonnego nie jest jednoznaczne z jego erygowaniem $^{30}$. Według V. de Paolisa następstwem erekcji domu zakonnego jest nabycie przez niego osobowości prawnej. Ustanowienie natomiast oznacza zwyczajne ustalenie, że w danym domu mogą mieszkać prawnie zakonnicy zgodnie z ich obowiązkiem prowadzenia życia braterskiego we wspólnocie. Termin ,ustanowienie” jest bardziej

${ }^{28}$ PAulus VI, Adhortatio apostolica, De religiosa vita secundum Concilii Oecumenici Vaticani II renovanda praeceptiones «Evangelica testificatio», 29 iunii 1971, AAS 63(1971)497-526; tekst polski, PAWE⿺ VI, Adhortacja apostolska, Wskazania na temat odnowy życia zakonnego wedtug nauki Soboru Watykańskiego II «Evangelica testificatio», nr 48, w: tenże, Charyzmat życia zakonnego. Przemówienia i dokumenty. Wybór i opracowanie A. Żuchowski, T. SuŁowsKA, Poznań-Warszawa 1974, s. 254-255 (odtąd: Evangelica testificatio).

${ }^{29} \mathrm{KPK} / 1983$, kan. $663 \S 2$.

${ }^{30} \mathrm{~V}$. DE PAolis, La vita consacrata nella Chiesa (edizione rivista e ampliata a cura di Vincenzo Mosca), Venezia 2010, s. 312: „Va anzitutto detto che la «costituzione» di una casa religiosa non è lo stesso che «l'erezione di una casa»"; J. BEYER, Il diritto della vita consacrata, s. 210; F.X. EGAÑIA, C'è differenza tra "casa legittamente costituita» e «casa eretta» (cc. 608 e 609)? In caso affermativo, quali sono le condizioni e le formalità necessarie per "costituire» una casa, senza che sia eretta in persona giuridica?, Vita Consacrata 27(1991)682. 
ogólny i nie oznacza aktu utworzenia osoby prawnej. Akt ustanowienia sprawia, że dom staje się domem zakonnym odpowiednim do zamieszkania przez zakonników. Zdaniem V. de Paolisa obecnie bardzo często się zdarza, szczególnie w przypadku instytutów podejmujących działalność apostolską, o dużej mobilności i wielu domach o charakterze tymczasowym, przejściowym i małej liczbie członków, że domy są tylko ustanowione, ponieważ ich ewentualna erekcja wiązałaby się z nabyciem przez nie osobowości prawnej, a osoby prawne ze swej natury są wieczyste (KPK/1983, kan. 120 §1). Inną przyczyną ustanowienia, nie zaś erekcji domu może być zamieszkiwanie przez zakonników budynku, który nie stanowi własności instytutu. Trzeba też zauważyć, że przełożony domu ustanowionego nie ma władzy zwyczajnej, lecz delegowaną i powinien podlegać przełożonemu innego domu erygowanego ${ }^{31}$.

Dla J. Torresa ${ }^{32}$ i D.J. Andrésa ${ }^{33}$ natomiast dom prawnie ustanowiony to dom erygowany. Zdaniem wymienionych autorów wszystkie domy zakonne powinny być erygowane, chociaż można tego dokonywać w różny sposób. Zdaniem J. Torresa nic nie stoi na przeszkodzie, aby kompetentny przełożony erygował dekretem formalnym dom, który nie może mieć osobowości prawnej, ponieważ tworzą go tylko dwaj zakonnicy, ale nie będzie on jednak częścią innego większego domu. Prawo własne instytutu powinno określić, jakie mogą być typy domów i procedurę ich erygowania ${ }^{34}$.

Zdaniem V. de Paolisa w sytuacji domu erygowanego podmiotem osobowości prawnej nie jest budynek, lecz zamieszkująca go wspólno-

${ }^{31}$ V. DE PAolis, La vita consacrata nella Chiesa..., s. 312; M. StoKŁosA, La figura del superiore provinciale..., s. 236.

${ }^{32}$ J. ToRres, Le case religiose ..., s. 7: ,....Dovremo concludere che i diversi tipi di casa possono essere eretti in modo diverso, ma tutti devono essere eretti”.

${ }^{33} \mathrm{D}$. ANDrÉs, Le forme di vita consacrata. Commentario teologico-giuridico..., s. 115-116: „La leggitima costituzione. - È la istituzione giuridica, la fondazione, il posizionamento della casa nell'ordine delle istituzioni o istituti interni per mezzo dell'atto e documento di erezione (c. 609). La erezione ha come effetto quello che la casa resta legittimamente costituita".

${ }^{34}$ J. TORREs, Le case religiose..., s. 7 
ta osób, która nabywa osobowość prawną w połączeniu z danym budynkiem. W tym znaczeniu dom zakonny to bardziej wspólnota niż budynek przez nią zamieszkany. Aby dom zakonny posiadał osobowość prawną, musi spełniać wymagane warunki, a te zgodnie z kan. 115 §2 dotyczą nie budynku, lecz osób, tj. wspólnoty składającej się w momencie erygowania domu zakonnego przynajmniej z 3 członków ${ }^{35}$.

KPK/1983 podaje $w$ dalszych kanonach wymagania dotyczące erekcji domu. Niektórzy autorzy uznają, że podobne wymagania potrzebne są również do ustanowienia domu ${ }^{36}$.

\section{Definicja domu zakonnego}

W oparciu o powyższe dociekania dotyczące elementów fundamentalnych domu zakonnego można sformułować jego definicję. Kanoniści pojęcie domus religiosa ujmują najczęściej w dwóch aspektach: formalnym i materialnym. W znaczeniu formalnym jest to wspólnota zakonników złożona przynajmniej z trzech, czasem też dwóch ${ }^{37}$ osób fizycznych złączonych więzami duchowymi wynikającymi z podobnej realizacji rad ewangelicznych $\mathrm{w}$ danym instytucie zakonnym; więzami prawnymi, czyli złożeniem profesji oraz apostolskimi, czyli dawaniem świadectwa życia konsekrowanego zgodnie z charyzmatem instytutu. Rysem charakterystycznym członków wspólnoty zamieszkującej dom jest pozostawanie pod władzą tego samego przełożonego wyznaczonego na urząd zgodnie z prawem. Przełożony nie może być tylko delegatem innego przełożonego, gdyż wówczas wspólnota, którą kieruje, nie tworzyłaby oddzielnego domu lecz część innego domu, podlegając jego przełożonemu. Dom zakonny stanowi najmniejszą jednostkę administracyjną instytutu zakonnego. Składając się przynajmniej z trzech osób przyjmuje on status kolegialnej osoby prawnej ${ }^{38}$.

${ }^{35}$ V. DE PAolis, La vita consacrata nella Chiesa..., s. 312.

${ }^{36}$ A. SKoruPA, Stuszna autonomia instytutów zakonnych $w$ Kościele łacińskim, Kraków 2002, s. 122-123; M.M. BILSKA, Obowiązek zamieszkania zakonnika ..., s. 74-84.

${ }^{37}$ D. Andrés, Le forme di vita consacrata. Commentario teologico-giuridico..., S. 114-115.

${ }^{38}$ KPK/1983, kan. 115, 116, 634; M. SitARZ, Stownik prawa kanonicznego, Warszawa 2004, s. 42; J. KaŁowski, Życie braterskie..., s. 55-59; J. KaŁowski, Prawo 
W znaczeniu materialnym dom zakonny to również siedziba, miejsce stałego zamieszkania wspólnoty zakonnej, obejmujące zarówno pomieszczenia mieszkalne zakonników, jak i budynki do niego przyległe oraz np. ogrody, przy czym nie ma znaczenia, czy dom, budynki i ogrody stanowią własność instytutu czy są tylko wydzierżawione zakonnikom na mieszkanie. Trzeba jednocześnie zauważyć, że sam fakt zamieszkiwania zakonników pod władzą przełożonego w budynku będącym nawet własnością instytutu nie tworzy jeszcze domu zakonnego, gdyż musi on zostać prawnie ustanowiony ${ }^{39}$.

Konkludując należy stwierdzić, że wbrew powszechnemu odnoszeniu terminu „dom zakonny” tylko do budynku, czyli pomieszczeń zamieszkiwanych przez zakonników, obejmuje on także zamieszkującą go wspólnotę pod władzą jednego przełożonego, a także sposób funkcjonowania wspólnoty skupionej wokół kaplicy jako miejsca sprawowania i przechowywania Eucharystii, będącej dzięki temu centrum wspólnoty. Poza tym nie można mówić o domu zakonnym bez jego prawnego ustanowienia ${ }^{40}$.

\section{Obowiązek przebywania przez zakonnika w domu zakonnym}

Życie zakonne zawsze łączyło się z zamieszkiwaniem zakonników w jednym domu zakonnym. Myśl tę próbowano wyrazić w obrazowych sentencjach dotyczących np. związku ryby z morzem. Podobnie jak ryba nie może żyć bez wody, tak też zakonnik nie jest w pełni zakonnikiem, jeżeli nie przebywa w domu zakonnym, jak czytamy już w Dekrecie Gracjana ${ }^{41}$. W instrukcji Kongregacji Instytutów Życia Konsekrowanego i Stowarzyszeń Życia Apostolskiego z 1994 r. o życiu braterskim we wspólnocie pt. Congregavit nos in unum Christi amor

o instytutach życia konsekrowanego wedtug Kodeksu Kanonów Kościołów Wschodnich, Warszawa 1994, s. 193; J.R. BAR, J. KaŁowski, Prawo o instytutach życia konsekrowanego, Warszawa 1985, s. 61-62; M. BIDER, Wydalenie fakultatywne z instytutu zakonnego wedtug Kodeksu prawa Kanonicznego, Lublin 2006, s. 77-78.

${ }^{39}$ KPK/1983, kan. 608; J.R. BAR, J. KAŁowsKi, Prawo o instytutach..., s. 62; F. BĄCZKowicz, Prawo kanoniczne..., s. 627-628.

${ }^{40} \mathrm{KPK} / 1983$, kan. 608.

${ }^{41}$ C. 16. q. 14. c. 8; KPK/1983, kan. 665§1; K. KAŁOwsKI, Życie braterskie..., s. 177. 
stwierdza się, że samotne zamieszkiwanie zakonnika nigdy nie jest ideałem i że powinien on przebywać we wspólnocie zakonnej zarówno sercem, jak i w sposób rzeczywisty ${ }^{42}$. Życie zakonne to doświadczenie wspólnoty braterskiej. Stąd wypływa też konieczność zamieszkiwania zakonników na stałe $\mathrm{w}$ domu communitas religiosa habitare debet in domo ${ }^{43}$, co KPK/1983 puentuje w sposób wyraźny: ,zakonnicy powinni mieszkać we własnym domu zakonnym, zachowując życie wspólne, i nie opuszczać go bez zezwolenia swego przełożonego"44. W kanonie tym pobrzmiewa decyzja Soboru Chalcedońskiego (451), który postanawiał, że mnichom nie wolno opuszczać klasztorów, chyba że w sytuacjach koniecznych nakaże im to biskup miasta ${ }^{45}$.

Prawodawca w KPK/1983 zobowiązuje zakonnika do zamieszkania nie w jakimkolwiek domu zakonnym należącym do instytutu, lecz w tzw. domu własnym instytutu ${ }^{46}$. Zadaniem prawa poszczególnych instytutów jest natomiast ustalenie sposobu wyznaczenia dla danego zakonnika konkretnego domu, który będzie jego domem własnym. Dla mnichów, mniszek i kanoników regularnych domem własnym sui iuris jest ten, w którym złożyli profesję rad ewangelicznych wiążącą ich na mocy ślubu stałości miejsca (stabilitas loci) z określonym klasztorem i zobowiązującą do stałego w nim zamieszkiwania. Warto zauważyć,

42 Congregazione per gli Istituti di Vita Consacrata e le Società di Vita ApoSTOLICA, La vita fraterna in comunità, "Congregavit nos in unum Christi amor», 2 februarii 1994, Libreria Editrice Vaticana 1994, nr 65; tekst polski, KongregacuA Instytutów Życia KonseKrowanego i Stowarzyszeń Życia Apostolskiego, Instrukcja Życie braterskie we wspólnocie, w: Życie konsekrowane w dokumentach Kościoła. Od Vaticanum II do Ripartire da Cristo (red. K. Wójtowicz), Kraków 2003², s. 499-548 (odtąd: Congregavit nos).

${ }^{43}$ KPK/1983, kan. 607 §2; G. SARZI SARTORI, Commento a un canone. L'Eucaristia al centro della comunità religiosa (c. 608), Quaderni di Diritto Ecclesiale 5(1992), s. 333 .

${ }^{44} \mathrm{KPK} / 1983$, kan. $665 \S 1$.

${ }^{45}$ Sobór ChalcedońsKi (451), Kanon 4. Mnichom nie wolno nic czynić wbrew woli własnego biskupa, budować klasztoru ani zajmować się sprawami światowymi, w: Dokumenty soborów powszechnych. Tekst grecki, łaciński, polski, t. I (325-787), Kraków 2002, s. 191-257; J. TORRES, L'assenza dalla casa religiosa, Informationes SCRIS 19(1993) nr 1, s. 77-78.

${ }^{46} \mathrm{KPK} / 1983$, kan. $665 \S 1$. 
że cenobici zawsze cenili stałość przebywania w jednym klasztorze i stąd tzw. mnisi wędrowni (gyrovagi) wędrujący po różnych okolicach i klasztorach uważani byli przez św. Benedykta za najgorszy rodzaj mnichów ${ }^{47}$. Dla pozostałych zakonników domem własnym jest ten, który wyznaczy im kompetentny przełożony instytutu zgodnie z prawem własnym tegoż instytutu, ponieważ profesja w tym wypadku włącza zakonnika tylko do instytutu lub prowincji, nie zaś do określonego domu. Wyznaczenie domu własnego następuje w tej sytuacji najczęściej w formie dekretu przełożonego lub zwykłego aktu administracyjnego obowiązującego zakonnika na mocy ślubu posłuszeństwa ${ }^{48}$.

Realnej obecności zakonników w domu wymaga konieczność wypełniania przez nich obowiązków wynikających z kan. 662-672 KPK/1983 r., czyli m.in. wspólnego odprawiania modlitw i innych pobożnych praktyk, zachowania porządku dnia, karności zakonnej, korzystania z ciszy i samotności zapewnianej przez klauzurę zakonną. Jednak, idąc za postanowieniem Soboru Chalcedońskiego przewidującego w niektórych sytuacjach możliwość pobytu zakonnika poza klasztorem, także obowiązujący KPK/1983 dopuszcza pewne wyjątki zgodnego z prawem przebywania zakonnika poza domem zakonnym najczęściej na określony czas ${ }^{49}$ oraz instytucję eksklaustracji ${ }^{50}$.

Także na krótką nieobecność zakonnika pozwolenia mogą udzielać zarówno przełożeni wyżsi instytutu, jak i lokalni zgodnie z przepisami prawa własnego ${ }^{51}$. Natomiast udzielenie pozwolenia na dłuższe prze-

${ }^{47}$ Benedykt z Nurssi, Reguła, nr 1.

48 J. ToRres, L'assenza dalla casa religiosa, s. 77-78; J. KAŁowsKI, Życie braterskie..., s. 192; M.M. BILSKA, Obowiazek zamieszkania zakonnika we własnym domu zakonnym (rozprawa doktorska napisana na KUL-u pod kierunkiem o. prof. B.W. Zuberta), Lublin 2010, s. 91-92 (maszynopis).

${ }^{49} \mathrm{KPK} / 1983$, kan. 665 §1. Gdyby zaś w jakimś instytucie większość członków nie żyła wspólnie w domach zakonnych lecz w rozproszeniu, samotnie i tylko spotykałaby się sporadycznie np. na święta, to nie można go nadal uznawać za prawdziwy instytut zakonny. Por. Congregavit nos, 65; J. KaŁowski, Życie braterskie..., s. 195.

${ }^{50} \mathrm{KPK} / 1983$, kan. 686, 687.

${ }^{51}$ Pojęcie i czas krótszej nieobecności formułuje s. M. M. Bilska w swej rozprawie doktorskiej, opierając się na interpretacjach znanych kanonistów. Autorka dochodzi do konkluzji, że krótsza nieobecność zamyka się w granicach od jednego dnia do 
bywanie zakonnika poza domem zakonnym KPK/1983 rezerwuje dla przełożonych wyższych za zgodą ich rad oraz dla Stolicy Apostolskiej. Prawo własne natomiast powinno dokładnie określić, co rozumie się przez dłuższą nieobecność, na którą nie może udzielić pozwolenia przełożony lokalny. Warto zauważyć, że według KPK/1917 r. na pobyt do 6 miesięcy udzielał pozwolenia własny przełożony instytutu, natomiast na dłuższy czas potrzebna była z zasady zgoda Stolicy Apostolskiej. Tej ostatniej nie wymagano w przypadku podjęcia studiów, wyniesienia do godności biskupiej, objęcia funkcji kapelana wojskowego, okrętowego, szpitala czy więzienia ${ }^{52}$.

Obowiązujący KPK z 1983 r. legalną dłuższą nieobecność zakonnika poza domem zakonnym dzieli na nieobecność nie przekraczającą roku oraz trwającą dłużej niż rok ${ }^{53}$. O zgodę na tę pierwszą może ubiegać się zakonnik kierujący się słuszną przyczyną, która czyni uzasadnionym wyjątek od powszechnego obowiązku przebywania we wspólnocie zakonnej. Przełożony wyższy, kompetentny do udzielenia pozwolenia za zgodą swej rady, rozpatruje z kolei każdy przypadek oddzielnie z uwzględnieniem konkretnej sytuacji zakonnika, gdyż dyspensa od przebywania w domu zakonnym udzielona bez słusznej i racjonalnej przyczyny jest wprawdzie ważna, ale niegodziwa. Jest też szkodliwa, ponieważ podważa autorytet ustawy i ustępuje miejsca arbitralności oraz woluntaryzmowi władzy udzielającej zgody ${ }^{54}$. Przyczyną słuszną i racjonalną, skłaniającą zakonnika do prośby o dyspensę może być kryzys powołania, który - jak się przewiduje - zostanie przezwyciężony dzięki przebywaniu w innym środowisku, konieczność odpoczynku, a także sprawy rodzinne, np. konieczność opieki

3 miesięcy i prawo własne powinno wyznaczyć przedział czasowy oraz przełożonego instytutu, do którego kompetencji należy udzielenie pozwolenia na pobyt poza domem zakonnym. M.M. BıLsKa, Obowiazek zamieszkania zakonnika..., s. 214-216.

${ }^{52}$ KPK/1917, kan. 606 §2; F. Bączkowicz, Prawo kanoniczne..., s. 723-724.

${ }^{53} \mathrm{KPK} / 1983$, kan. 665.

${ }^{54}$ KPK/1983, kan. 90 §1; J. KaŁowsKI, Życie braterskie..., s. 197-198; Kodeks Prawa Kanonicznego. Komentarz, Edycja polska na podstawie wydania hiszpańskiego (red. nauk. P. Majer), Kraków 2011, s. 123-124; J. ToRRES, Obblighi dei religiosi (dal can. 665 al 672), Roma 2001, s. 5. 
nad członkiem bliskiej rodziny. Ze strony instytutu przyczyną udzielenia zakonnikowi dyspensy może być potrzeba rozpoznania miejsca na nową fundację, praca na rzecz powołań, opieka nad dobroczyńcami instytutu $^{55}$. Zakonnik prawnie przebywający poza domem zakonnym pozostaje nadal członkiem instytutu ze wszystkimi prawami i obowiązkami przysługującymi innym członkom instytutu, wyłączając te, które nie dadzą się pogodzić z jego nową sytuacją, jak np. częste udawanie się po pozwolenie do przełożonego czy zachowanie klauzury ${ }^{56}$.

Może się też zdarzyć, że zakonnik przebywa poza domem zakonnym w sposób bezprawny, czyli bez wymaganego pozwolenia kompetentnego przełożonego, z zamiarem uwolnienia się spod władzy przełożonego. W takiej sytuacji powinien on być przez przełożonych usilnie nakłaniany do powrotu do domu zakonnego i wytrwania w powołaniu $^{57}$. Gdyby jednak zakonnik nie chciał powrócić, a jego bezprawny pobyt trwał pół roku lub dłużej, przełożony wyższy za zgodą swej rady może wszcząć proces o wydalenie go z instytutu ${ }^{58}$.

Na uzasadniony dłuższy pobyt zakonnika po ślubach wieczystych poza domem zakonnym w pozwala także wspomniana wyżej instytucja eksklaustracji. Na prośbę zakonnika indultu eksklaustracji zwykłej (exclaustratio simplex) udziela najwyższy przełożony instytutu za zgodą swej rady na okres do trzech lat. Przedłużenia indultu lub wydania go na czas dłuższy niż trzy lata może dokonać Stolica Apostolska, gdy instytut jest na prawie papieskim, lub biskup diecezjalny, kiedy instytut pozostaje na prawie diecezjalnym. Udzielenie indultu eksklaustracji mniszkom zarezerwowane jest zawsze dla Stolicy Apostolskiej ${ }^{59}$. Przyczyna zwrócenia się zakonnika o indult eksklaustracji musi być poważna, prawdziwa, słuszna i racjonalna. Do najczęstszych należą:

${ }^{55}$ A. Calabrese, Istituti di vita consacrata ..., s. 261; J. KalowsKi, Życie braterskie..., s. 199.

${ }^{56}$ B.W. ZUBERT, Instytuty życia konsekrowanego i stowarzyszenia życia apostolskiego..., s. 164.

${ }^{57} \mathrm{KPK} / 1983$, kan. 665 §; M. SAJ, Konstytutywne elementy domu zakonnego, S. 156.

${ }^{58}$ KPK/1983, kan. 696 § 1, kan. 697.

${ }^{59} \mathrm{KPK} / 1983$, kan. $686 \S 1,2$. 
opieka nad chorymi, starszymi rodzicami lub innym członkiem rodziny, kryzys powołania zakonnego, brak zdrowia, założenie nowego instytutu itp., a także przyczyny ze strony instytutu, podobnie jak to było w przypadku prawnego pobytu poza domem zakonnym ${ }^{60}$.

Zakonnik eksklaustrowany pozbawiony jest głosu czynnego i biernego oraz zostaje zwolniony $\mathrm{z}$ tych obowiązków, które nie dadzą się pogodzić z jego nowymi warunkami życia. Podlega on nadal właściwym przełożonym, a w przypadku duchownych również ordynariuszowi miejsca. Może nosić strój zakonny, chyba że w indulcie inaczej postanowiono ${ }^{61}$. Eksklaustracja może też zostać nałożona (exclaustratione imposita) na zakonnika jako sankcja karna wbrew jego woli przez Stolicę Apostolską lub biskupa diecezjalnego w zależności od tego, na jakim prawie jest instytut, na prośbę najwyższego przełożonego za zgodą jego rady. Czas trwania eksklaustracji nałożonej określa Stolica Apostolska lub biskup diecezjalny, ale zasadniczo jest ona udzielana na czas nieokreślony. Instytut zaś ma obowiązek wesprzeć eksklaustrowanego zakonnika, jeśli ten nie jest w stanie sam się utrzymaćc ${ }^{62}$.

\section{Sens zamieszkiwania przez zakonnika w domu prawnie ustanowionym}

Powstaje zatem pytanie: dlaczego prawodawcy kościelnemu tak bardzo zależy na zamieszkiwaniu przez zakonnika we własnym domu zakonnym prawnie ustanowionym i tylko na zasadzie wyjątku i zazwyczaj na krótki czas pozwala mu na jego opuszczenie?

${ }^{60}$ W. KIWIOR, Procedura obowiązująca przy eksklaustracji, sekularyzacji $i$ wydaleniu z instytutu życia zakonnego, Prawo Kanoniczne 38(1995) nr 3-4, s. 122; J. KowAL, Indult eksklaustracji w normach Kodeksu Prawa Kanonicznego i praktyce Kurii Rzymskiej, Prawo Kanoniczne 40(1997) nr 1-2, s. 118-120; J. KaŁowsKi, Życie braterskie..., s. 235; V. DE PAolis, La vita consacrata nella Chiesa..., s. 562; A. CALABrese, Istituti di vita consacrata..., s. 279.

${ }^{61} \mathrm{KPK} / 1983$, kan. 687.

${ }^{62}$ J. KowaL, Indult eksklaustracji w normach Kodeksu Prawa Kanonicznego..., s. 129-138; J. Beyer, Il diritto della vita consacrata, Milano 1989, s. 354-355; J. KaŁowsKi, Życie braterskie..., s. 242-253. 
Wydaje się, że istota przebywania w domu zakonnym wiąże się z samym pojęciem zakonnika i życia zakonnego, których zasadniczymi elementami i obowiązkami są: prowadzenie życia braterskiego we wspólnocie, złożenie publicznych ślubów czystości, ubóstwa i posłuszeństwa oraz oddzielenie od świata, zgodnie z charakterem danego instytutu $^{63}$. To właśnie zamieszkiwanie $\mathrm{w}$ domu zakonnym umożliwia zakonnikowi realizację wymienionych obowiązków. Stąd można pokusić się o stwierdzenie, że zakonnik bez zamieszkania w domu zakonnym nie może być w pełni zakonnikiem.

\subsection{Oddzielenie od świata}

Dom zakonny zapewnia zakonnikom niezbędne dla ich życia odseparowanie od świata przez instytucję klauzury właściwą każdemu instytutowi zakonnemu i dostosowaną do charakteru oraz misji każdego $\mathrm{z} \mathrm{nich}^{64}$. Termin klauzura nawiązuje do łacińskiego słowa claustrum, $i$, które stosowano także jako synonim domu zakonnego, tj. klasztoru. Stanowi ona kontynuację dawnej ucieczki ze świata (fuga mundi) tych, którzy pragnęli poświęcić swe życie Bogu ${ }^{65}$. Utożsamianie klauzury z domem zakonnym świadczy o ważnym znaczeniu dla życia zakonników oddzielenia od świata, a tym samym o roli domu w sensie materialnym, który je zapewnia ${ }^{66}$. Zakonnikom właściwe jest fizyczne

\footnotetext{
${ }^{63} \mathrm{KPK} / 1983$, kan. $607 \S 2$.

${ }^{64} \mathrm{KPK} / 1983$, kan. 667.
}

65 J. LeClercQ, Clausura, DIP, t. II, Roma 1975, kol. 1166; J. Sondel, Stownik łacińsko-polski dla prawników i historyków, Kraków 1997, s. 158; A. JougAN, Słownik kościelny łacińsko-polski, Warszawa $1992^{3}$, s. 114; F. BoGDAN, Geneza i rozwój klauzury zakonnej, Poznań 1954, s. VII-VIII.

${ }^{66}$ Paulus VI, Litterae apostolicae motu proprio datae. Normae ad quaedam exsequendae SS. Concilli Vaticani II Decreta statuuntur «Ecclesiae Sanctae», 6 septembris 1966, AAS 58(1966)757-782; tekst polski: PAWEŁ VI, Motu proprio Ecclesiae Sanctae, nr 31, w: tenże, Charyzmat życia zakonnego. Przemówienia i dokumenty, opr. A. Żuchowski, T. Sułowska, Poznań-Warszawa 1974, s. 222-223 (odtąd: Ecclesiae Sanctae); F. Bogdan, Geneza i rozwój klauzury..., s. VII; L. ChiAPEtTA, Il codice di diritto canonico. Commento giuridico-pastorale, t. I, s. 811; J. Prou, (e le monache della Congregazione di Solesmes, O.S.B.), La clausura delle monache, prospettive della vita religiosa, Città del Vaticano 1998, s. 15-17. 
i zewnętrzne oddzielenie od spraw świata, nie zaś tylko duchowe, jak w przypadku innych form życia konsekrowanego (instytutów świeckich, stanu dziewic) czy w ogóle chrześcijan ${ }^{67}$. Zadaniem bowiem klauzury zakonnej jest ograniczenie osobom obcym wchodzenia do budynków zamieszkanych przez zakonników i wychodzenia z nich zakonników bez pozwolenia przełożonego ${ }^{68}$. Obecnie, w dobie sekularyzacji, znaczenie domu i klauzury polega - jak się wydaje - na zapewnieniu zakonnikom ciszy, skupienia, milczenia i samotności oraz ochrony przed wszelkim próżnym zamieszaniem, czyli tego wszystkiego, co jest potrzebne do bliskiego kontaktu z Bogiem. Klauzura chroni zakonników przed ucieczką z klasztoru „do” świata, jak słusznie zauważa R. Cantalamessa ${ }^{69}$. Zapewnia ona przestrzeń do realizacji podstawowego obowiązku zakonników, tj. kontemplacji rzeczy Bożych i ustawicznego zjednoczenia z Bogiem w modlitwie, zarówno tym, którzy oddają się kontemplacji, jak i tym, którzy szukają Go wśród zgiełku i hałasu świata, wykonując zadania apostolskie ${ }^{70}$. Oddzielenie od świata wpisane w naturę życia zakonnego z racji zamieszkania zakonników w domu zakonnym objętym przynajmniej częściowo klauzurą pozwala na dłuższe trwanie przez Panem na modlitwie i adoracji, uczestni-

${ }^{67}$ Kongregacja Zakonów I Instytutów Świeckich, Instrukcja o życiu kontemplacyjnym i o klauzurze mniszek «Venite seorsum», 15 VIII 1969, AAS 61(1969)674-690, tekst polski w: Paweł VI, Charyzmat życia zakonnego. Przemówienia i dokumenty, opr. A. Żuchowski, T. Sułowska, Poznań-Warszawa 1974, s. 287-288.

${ }^{68}$ L. Choupin, Istota i obowiazki stanu zakonnego, Kraków 1930, s. 291; F. Bogdan, Geneza i rozwój klauzury..., s. VIII; J. R. BAR, Prawo zakonne po Soborze Watykańskim II, Warszawa 1977, s. 243; J. KAŁowsKI, Prawo o instytutach życia konsekrowanego wedtug Kodeksu Kanonów Kościołów Wschodnich, Warszawa 1994, s.123.

${ }^{69} \mathrm{R}$. CAntalamessa, L'ideale della separazione dal mondo nella vita religiosa di oggi, Informationes SCRIS 17/1(1991)116.

${ }^{70}$ Paulus VI, Adhortatio apostolica, De religiosa vita secundum Concilii Oecumenici Vaticani II renovanda praeceptiones «Evangelica testificatio», 29 iunii 1971, AAS 63(1971)497-526; tekst polski: PAWEL VI, Adhortacja apostolska, Wskazania na temat odnowy życia zakonnego wedtug nauki Soboru Watykańskiego II «Evangelica testificatio», w: tenże, Charyzmat życia zakonnego. Przemówienia i dokumenty. Wybór i opracowanie A. Żuchowski, T. Sułowska, Poznań-Warszawa 1974, s. 254; KPK/1093, kan. 663; Сн.C. Sторен, L'istruzione sulla vita contemplativa e la clausura delle monache «Verbi sponsa», Informationes SCRIS 25/2(1999)148. 
czenie w Eucharystii oraz rozważanie Słowa Bożego czemu sprzyja istnienie $\mathrm{w}$ domu zakonnym kaplicy. To tu zakonnicy mogą praktykować wszystkie pobożne ćwiczenia w ciszy klauzury, bez wychodzenia z domu zakonnego. Poza tym świadomość konieczności rzeczywistego oddzielenia od świata, tak rygorystycznego w początkach życia monastycznego, powinna ułatwiać współczesnym zakonnikom takie korzystanie ze środków społecznego przekazu, aby uniknąć wszystkiego, co przynosi szkodę powołaniu i jest zagrożeniem dla konsekracji. Obecnie bowiem zakonnik zachowując nawet klauzurę w sensie materialnym, tak naprawdę może żyć ciągle poza nią, pozwalając na wejście do swej celi hałasu i informacji, a pośrednio także osób dzięki nowoczesnym środkom komunikacji międzyludzkiej ${ }^{71}$.

Wyrazem oddzielenia od świata jest również habit zakonny, który dzięki jednolitości i nieuleganiu modzie odróżnia zakonników od wiernych świeckich. Stanowi on jednocześnie świadectwo poświęcenia się Bogu, prostoty, pokuty i realizacji ewangelicznej rady ubóstwa. KPK/1917 nie zezwalał na noszenie stroju zakonnego zakonnikom wydalonym, sekularyzowanym lub eksklaustrowanym, a więc tym, którzy przebywali poza domem zakonnym ${ }^{72}$.

\subsection{Wspólnota zakonna znakiem Kościoła-komunii}

Sens zamieszkiwania zakonników w domu zakonnym sprowadza się także do umożliwienia im w sposób najpełniejszy realizacji braterstwa posuniętego aż do ciągłego, wspólnego przebywania pod jednym dachem. To właśnie domy zakonne dzięku zamieszkującym je wspólnotom zakonnym ukazują, że braterstwo chrześcijan jest możliwe i jak wysoką cenę trzeba zapłacić, aby odzwierciedlało ono i urzeczywist-

${ }^{71}$ KPK/1983, kan. 666; Congregatio pro Institutis Vitae Consecratae et Societatibus Vitae Apostolicae, Norme directivae de institutione in relilgiosis institutis, «Potissimum institutionis» 02.02.1990, AAS 82(1990)470-532, nr 13, tekst polski w: Życie konsekrowane w dokumentach Kościoła. Od Vaticanum II do Ripartire da Cristo (red. Kazimierz Wójtowicz), Kraków 2003², s. 377 (odtąd: Potissimum institutionis); M.M. BILSKA, Obowiązek zamieszkania zakonnika..., s. 184-185.

${ }^{72}$ KPK 1917, kan. 639-640. 
niało w świecie Kościół-komunię ${ }^{73}$. Domy zakonne powinny więc stanowić środowisko sprzyjające tworzeniu głębokich więzi braterskich będących widzialnym znakiem braterstwa ofiarowanego Kościołowi przez Chrystusa ${ }^{74}$. Autentyzm zaś życia braterskiego wspólnoty zakonnej ujawnia się światu m.in. w apostolacie. Już sama komunia braterska dzięki więzom miłości, jakie winny w niej panować, stanowi formę apostolatu. Jest ona właściwa klasztorom kontemplacyjnym, nieprowadzącym działalności apostolskiej ${ }^{75}$. Natomiast w przypadku instytutów pełniących posługi apostolatu poszczególni zakonnicy działają zawsze w imieniu całej wspólnoty ${ }^{76}$.

\subsection{Realizacja ślubów zakonnych}

Zamieszkiwanie zakonników w domu zakonnym w odróżnieniu od innych, np. indywidualnych form życia konsekrowanego, pociąga za sobą specyficzną realizację ślubów czystości ubóstwa i posłuszeństwa, nazywanych w odniesieniu do zakonników ślubami zakonnymi.

Ślub ubóstwa zakonnego ze względu na wspólne przebywanie zakonników w jednym domu oraz prowadzenie i utrzymanie dzieł instytutu wymaga przekazania przez nich wspólnocie całego swego dochodu z wykonywanej pracy, z tytułu ubezpieczenia lub zapomogi, ale też otrzymywania tego, czego potrzebują oni do życia i swej działalności ${ }^{77}$. Wspólne zamieszkiwanie $\mathrm{w}$ domu zakonnym skłania zakonników do pragnienia, aby „wszystko było wspólne” i aby „każdemu rozdzielano według potrzeby"78. Wyrazem ślubu ubóstwa jest

${ }^{73}$ Congregavit nos, 2, 56.

${ }^{74}$ Tamże, 2.

${ }^{75} \mathrm{~J}$ 13, 35: „Po tym wszyscy poznają, żeście uczniami moimi, jeżeli będziecie się wzajemnie miłowali"; Congregavit nos, 54-55.

${ }^{76}$ Congregavit nos, 55.

${ }^{77} \mathrm{PC}, 13$; KPK/1983, kan. 669§1: „§ 3. Cokolwiek zakonnik nabywa własnym staraniem albo ze względu na instytut, nabywa to dla instytutu. Wszystko, co mu przysługuje $\mathrm{z}$ tytułu pensji, zapomogi lub ubezpieczenia, jest nabywane dla instytutu, chyba że własne prawo co innego postanawia"; E. GAMBARI, Życie zakonne po Soborze Watykańskim II, Kraków 1998, s. 355-356.

${ }^{78}$ Dz 4, 32-35; Potissimum institutioni, 14. 
również obowiązek pracy. Zakonnicy i członkowie stowarzyszeń życia apostolskiego, w odróżnieniu od członków instytutów świeckich oraz indywidualnych form życia konsekrowanego, najczęściej wykonują ją wspólnie w ramach prowadzonych dzieł apostolskich przylegających często do domu zakonnego ${ }^{79}$.

Realizacja zakonnego ślubu czystości różni się od praktykowania tej rady ewangelicznej np. przez członków instytutów świeckich oraz członkiń stanu dziewic. W obu formach rady ewangeliczne realizuje się w świecie na wzór wiernych świeckich, natomiast dom zakonny i oddzielenie w nim od świata dzięki klauzurze chroni np. przed wielością kontaktów osobistych, odbywaniem długich rozmów, a także nieuzasadnionym przedłużonym przebywaniem poza domem zakonnym. Warto zauważyć, że dokumenty kościelne dotyczące zakonników zgodnie podkreślają dobrodziejstwo życia wspólnego w domu zakonnym, gdzie „łatwiej jest zachować czystość, gdy wśród członków panuje prawdziwa miłość braterska w życiu wspólnym" ${ }^{80}$ przypominają też, że ,jakość życia braterskiego wpływa decydująco na wytrwanie w powołaniu poszczególnych zakonników"81.

Ślub posłuszeństwa zakonnego również jest realizowany w specyficzny sposób w związku ze wspólnym zamieszkiwaniem zakonników. Wprawdzie im, jak i pozostałym osobom konsekrowanym, posłuszeństwo wobec przełożonych ma służyć pomocą w naśladowaniu Chrystusa posłusznego woli Ojca aż do śmierci, to jednak codzienne realizacja tego ślubu przyjmuje bardziej radykalne formy ze względu na zwyczajną konieczność zachowania porządku we wspólnocie i domu zakonnym, zharmonizowania pracy z pracą pozostałych członków wspólnoty i skuteczność obowiązków domowych ${ }^{82}$. Dzięki przebywaniu razem, wspólnej modlitwie i pracy zakonnicy mogą prowadzić rozmowy między sobą i z przełożonym, co sprzyja dialogowi, tak istotnemu, a nawet niezbędnemu elementowi posłuszeństwa zakonnego ${ }^{83}$.

\footnotetext{
${ }^{79} \mathrm{KPK} / 1983$, kan. 600.

${ }^{80} \mathrm{PC}, 12$.

${ }^{81}$ Congregavit nos, 57.

${ }^{82}$ E. GAmBARI, Życie zakonne po Soborze Watykańskim II, s. 382.

${ }^{83}$ PC, 14; E. GAMBARI, Życie zakonne po Soborze Watykańskim II, s. 397.
} 


\section{Zakończenie}

Życia zakonnego nie można zrozumieć i przyjąć bez nieodłącznie z nim związanego domu zakonnego, pojmowanego najczęściej jako budynek i miejsce zamieszkania zakonników. Tymczasem szczególnie dla samych zakonników wydaje się bardzo ważne właściwe rozumienie domu zakonnego, czyli obejmowanie tym pojęciem również wspólnoty zakonników łącznie z przełożonym, a także całokształt życia wspólnoty ze szczególnym uwzględnieniem jego wymiaru duchowego skupionego wokół kaplicy zakonnej stanowiącej konieczną część domu. Tak pojęty dom zakonny stanowi codzienne środowisko życia zakonników, warunkuje realizację przez nich rad ewangelicznych, wypełnianie innych obowiązków zakonnych i - ogólnie rzecz ujmując - sprzyja lub nie dążeniu do osiągnięcia doskonałej miłości Chrystusa, co stanowi zasadniczy cel ich konsekracji. Stąd tak ważne jest, aby w momencie zakładania domu zakonnego zostały uwzględnione wszystkie jego konstytutywne elementy wymienione w kanonie 608 i 609 KPK/1983.

\section{The concept of a religious house and its importance to the religious life}

Religious life and the practice of community life that is related to it entails religious residence in the religious house. The understanding (comprehension) of the religious house even by the religious themselves is very often limited to the building in which the religious reside. The task of the author, based on her conducted research, was to formulate the correct definition of the religious house resulting from Canons 608 and 609 CIC 1983, and to show its relevance for a religious in her/his pursuit of holiness. It turns out that in addition to building the concept of a religious house includes the community of religious living under the jurisdiction of a superior as well as the entirety of life of that community with the particular emphasis on its spiritual dimension centered around the religious house chapel which is the necessary part of the house. Hence it is important that at the time of the establishment of a religious house were taken into account all of its constituent elements which are mentioned in Canons 608 and 609 CIC 1983. 